IZA DP No. 5972

Duration of Low Wage Employment:

A Study Based on a Survival Model

António M. S. Pimenta

Francisco J. F. Silva

José A. C. Vieira

September 2011 


\title{
Duration of Low Wage Employment: A Study Based on a Survival Model
}

\author{
António M. S. Pimenta \\ University of the Azores \\ Francisco J. F. Silva \\ CEEApIA, University of the Azores \\ José A. C. Vieira \\ CEEApIA, University of the Azores \\ and IZA
}

\section{Discussion Paper No. 5972 \\ September 2011}

\author{
IZA \\ P.O. Box 7240 \\ 53072 Bonn \\ Germany \\ Phone: +49-228-3894-0 \\ Fax: +49-228-3894-180 \\ E-mail: iza@iza.org
}

Any opinions expressed here are those of the author(s) and not those of IZA. Research published in this series may include views on policy, but the institute itself takes no institutional policy positions.

The Institute for the Study of Labor (IZA) in Bonn is a local and virtual international research center and a place of communication between science, politics and business. IZA is an independent nonprofit organization supported by Deutsche Post Foundation. The center is associated with the University of Bonn and offers a stimulating research environment through its international network, workshops and conferences, data service, project support, research visits and doctoral program. IZA engages in (i) original and internationally competitive research in all fields of labor economics, (ii) development of policy concepts, and (iii) dissemination of research results and concepts to the interested public.

IZA Discussion Papers often represent preliminary work and are circulated to encourage discussion. Citation of such a paper should account for its provisional character. A revised version may be available directly from the author. 
IZA Discussion Paper No. 5972

September 2011

\section{ABSTRACT}

\section{Duration of Low Wage Employment: A Study Based on a Survival Model}

This paper includes a survival analysis which attempts to explain the duration, as in the number of years a worker remains in a low wage situation. Explanatory variables take into account the characteristics of the employee, such as education, age, tenure with the company, gender and nationality, and the characteristics of the job and the company such as industry affiliation, number of employees, age of the company and location.

JEL Classification: $\quad \mathrm{J} 31, \mathrm{~J} 42$

Keywords: $\quad$ low wage, survival, Portugal

Corresponding author:

Francisco J. F. Silva

CEEApIA - University of the Azores

Rua da Mãe de Deus

9501-801 Ponta Delgada

Portugal

E-mail: fsilva@uac.pt 


\section{Introduction}

According to OCDE (1999), the importance of investigating the evolution of the low-wage situation of workers is based on at least three factors. First, the reduction of low-wage employment should contribute significantly to decreased poverty, since salaries are the main source of income for many families. Second, the perspective of a low salary could discourage employment offers from individuals when they are aware of income alternatives such as unemployment compensation or income support programs. Finally, the perspective of a low income could create incentives to join the informal or parallel job market to avoid, for example, taxes.

Analysis of wage mobility of these workers is important from the point of view of public policies. In particular, from the point of view of public decision making, it is important to know to what extent low wages constitute permanent or temporary solutions. Temporary solutions due to the lack of accumulated human resources through experience, whose abandonment is resolved by the market, are differentiated, from the point of view of public and social policies, from permanent solutions related to existing barriers and flaws in the job market.

In fact, in recent years, perhaps for the above reasons, the interest in studying the mobility of low wage workers has increased. Between the existing studies and publications on the subject, there are the works of Gregory and Elias (1994), Sloane and Theodossiou (1996), OCDE (1996 and 1997), Lucifora and Salverda (1998), Asplund et al. (1998), Stewart and Swaffield (1999), Cappellari (2000, 2002 e 2007), Bazen (2001), Deding (2002), Holzer et al. (2004), Vieira (2005), Cuesta (2006 e 2008) and Mosthaf et al. (2011) among others.

This study intends to contribute to the literature on the profile and earning mobility of low wage workers, making use of data from Portugal, a country of high wage inequality (Cardoso, 1998 and 2006). 
This study is organized as follows: section 2 is a review of literature on wage mobility, section 3 defines low wage workers, section 4 displays the results of the empirical analysis and section 5 presents the main conclusions.

\section{Literature review.}

One of the most focused on themes in literature is the capacity shown by low wage workers of abandoning this situation with time, as well as the determining factors of such likelihood (Gregory and Elias, 1994, Sloane and Theodossiou, 1996, 1998 and 2000, OCDE, 1996, Gosling et al., 1997, Asplund et al., 1998, Van Opstal et al., 1998, Arai et al., 1998, Stewart e Swaffield, 1999, Cappellari, 2000, 2002 e 2007, Bazen 2001, Deding, 2002, Holzer, 2004, Vieira, 2005, Cuesta, 2006 and 2008, and Mosthaf et al., 2011). In particular, the literature attempts to clarify to what extent low earnings constitute a transitional situation or, on the contrary, corresponds to a prolonged or permanent scenario, affecting specific groups of workers.

The effect of some characteristics on the employee's side observed by the researcher, on the likelihood of abandoning the low wage situation has been widely referenced in empirical literature. Sloane and Theodossiou (2000) concluded that, in the United Kingdom, there is a high upward mobility of low wage workers between youths and those with higher education. However, for a significant number of employees such as women, the less educated and the aged, the low wage situation tends to be persistent and lasting once in it. Similar results were obtained in Portugal by Vieira (2005) and Germany by Mosthaf et al. (2011).

Deding (2002) concluded that women are at a greater risk than men of remaining low-wage employees in Denmark and the USA. It also concludes that in Denmark, the change of marital status (from married to divorced or widowed) increases the likelihood of retaining low wages. More education lowers this likelihood in Denmark and Germany. 
Gregory and Elias (1994) confirmed the existence of greater upward mobility of wages of younger workers, especially men in the United Kingdom. In another study, for the United Kingdom Stewart and Swaffield (1999) show evidence of greatly persisting low income, especially women. They also state that education and professional experience reduces the likelihood of retaining low wages. They found evidence that unionized employees have less likelihood of retaining a low income.

Asplund et al. (1998) studies the mobility of low-wage employees in Denmark and Finland, concluding that the acquisition of specific skills linked to occupation and human resources in general contribute to getting out of that situation. In the Netherlands, Van Opstal et al. (1998) found that the accumulation of human resources of the company in an extended period of time is much less contributing to wage mobility of those employees than the human resources gathered from experience in the job market.

Gosling et al. (1997) also stressed the importance of human resources on wage mobility in the United Kingdom, but the main driving force of this process is the experience of the employee on the job. Pavlopoulos et al. (2005) stated that highly qualified workers present greater wage mobility than less qualified colleagues in countries such as France, Netherlands, Finland, England and Greece. On the other hand, low qualifications are associated with greater wage mobility in Austria, Italy, Spain and especially Denmark. They did not find a clear standard for Portugal and Ireland cases.

According to Arai et al. (1998), there are occupations of typically low wages, where human resources are not very crucial to mobility. The only way to escape low income in this scenario is likely through changing jobs, as suggested by Mosthaf et al. (2011).

Several studies also point to an effect of factors in seeking (employment), such as occupation/profession, the size and location of the company and field of activity, 
among others, in the likelihood of the individual leaving the low-wage worker position.

According to Stewart and Swaffield (1999) there is a negative relationship between the size of the enterprise and the persistence of low income. In a comparative study between Germany and Austria, Grün et al., (2009) acknowledge that the size of the company has a positive impact on wage mobility in both countries. Larger companies may possibly have internal job markets and better perspectives of career promotions. Sloane and Theodossiou (1996) also found a smaller likelihood of employees in companies with more than 500 workers remaining in a low-wage situation. Similar results were displayed by Vieira (2005) and Blázquez (2006).

Aware of a correlation over time between the unobserved selection of the sample could lead to partial estimates and attempts to manipulate it in their wage mobility study in Italy, Sloane and Theodossiou (1996) divided it in two employment types: intellectual and non-intellectual. They observed that wage mobility is not high, and that certain groups of non-intellectual occupations and employees of small companies have a strong likelihood of receiving low wages.

Vieira (2005) and Blásquez (2006), acknowledged that low wage workers in certain economic activities have a smaller likelihood of progressing in wage distribution. Cappellari (2000) concluded that the characteristics called for such as occupation and the size of the company are more important in explaining the persistence of low income than the characteristics of the individual.

According to Mosthaf et al. (2011), in their study for Germany, companies with an elevated proportion of low wage workers offer them few opportunities to get out of this situation. The same applies to those found in occupations with a high percentage of low income. They state that remaining in these companies or occupations is to perpetuate the situation, mentioning a change of company or occupation as a way to escape it. 


\section{Defining the Low Wage Worker}

The economic theory does not provide a definition for low income. Therefore, the definition used in empirical literature is somewhat arbitrary. According to the OCDE (1996), low income can be defined in absolute terms or relative terms.

The absolute measurement defines a low wage worker as one earning less than the minimum level considered to warrant a certain purchasing power or subsistence. This measure has the disadvantage of varying over time and between countries, making comparisons more difficult.

The relative measurement solves some of these issues, but has the limitation of lacking a clear limit under which the employee could be considered a low wage worker. Some points of income distribution used in the literature, below those low wage workers are found in are: the third decile (Sloane and Theodossiou, 1994); the first quartile (Pavlopoulos et al., 2007); the third decile (Contini et al., 1998); the second decile (Gregory and Elias, 1994, Contini et. al. 1998). Aside from the arbitrary nature of these measures, another disadvantage is the fact that by definition, they do not allow any variation in the percentage of low wage employees over time or between countries.

The most used measure in the literature is two thirds of the income distribution median, which has the advantage of, with its structure, to allow changes in the percentage of employees in a low wage situation over time and in different countries. Some studies using this measurement are OCDE (1997), Deding (2002) Keese et al. (1998), Sloane and Theodossiou (1998), Vieira (2005), Cuesta (2006 e 2008), Blázquez (2006), Mosthaf et al. (2011).

In regard to salaries, and in the scope of relative measurements, these could be gross or net. They could be also monthly, weekly, daily or hourly based. However, due to discrepancy of working hours between different employees, the hourly rate seems to 
be the one ensuring more reliable comparisons (Cardoso, 1997 and Blázquez, 2006). A significant part of literature uses raw hourly wages.

\section{The Survival Model}

Survival analysis is a technique that allows study of the time passed before a certain event. It determines not only whether an event will occur but also when it should occur. The survival analysis results in two types of information: the survival function - proportion of the population that survives a certain time period, and the hazard function - proportion of the population which survived a certain period of time and will likely reach the terminal event in this period.

Calculating the survival model uses the method of maximum likelihood with censored data left and right. It is known that the period of low income lasted up to $t_{i}$ (duration observed in the sample), the likelihood of this event is given by the survival function $S\left(t_{i} \mid X_{i}\right)$, with the vector of explaining variables being $X_{i}$.

If we define:

$$
d_{i}=\left\{\begin{array}{c}
1 \text { observation } i \text { is not censored } \\
0 \text { observation } i \text { is censored }
\end{array}\right.
$$

The likelihood function will be represented by:

$$
L(\theta)=\prod_{i=1}^{N} f\left(t_{i} \mid X_{i}\right)^{d_{i}} S\left(t_{i} \mid X_{i}\right)^{\left(1-d_{i}\right)}
$$

Where $\theta$ represents the vector of parameters including the vector with the specific regression parameters, and the parameters of the functions distribution and $f($.) represent the density function of the duration variable $T_{i}$, $\left(t_{i}\right.$ being a concretization of variable $\left.T_{i}\right)$.

The logarithmic likelihood function is given by:

$$
l(\theta)=\sum_{i=1}^{N}\left[d_{i} \log f\left(t_{i} \mid X_{i}\right)+\left(1-d_{i}\right) \log S\left(t_{i} \mid X_{i}\right)\right]
$$


with $f\left(t_{i} \mid X_{i}\right)=\lambda\left(t_{i} \mid X_{i}\right) S\left(t_{i} \mid X_{i}\right)$ the function can be written as:

$$
l(\theta)=\sum_{i=1}^{N}\left(d_{i} \log \lambda\left(t_{i} \mid X_{i}\right)-\Lambda\left(t_{i} \mid X_{i}\right)\right), \text { with } \Lambda\left(t_{i} \mid X_{i}\right)=-\log S\left(t_{i} \mid X_{i}\right)
$$

The maximum likelihood estimate results from the first order condition to maximize function $l(\theta)$.

\section{Empirical analyses}

The sample used represents low wage workers in the year 2003 (below 2/3 of the median income), resulting in 333890 observations, excluding those with workers who were already in this situation before 2003 and those who were still in this situation in 2008 .

It intends to explain the number of years required to depart from low income. Figure 1 shows the number of years spent by workers who were in this situation in 2003 to get out of it.

\section{Please insert Figure 1 about here}

Of most employees who got out of a low wage situation, about $40 \%$ left it within a year. Only $1.2 \%$ of them required six years to abandon the low wage situation.

Table 1 summarizes the information on categorized explanatory variables. As seen in the table, about $63 \%$ of the ones observed are female while $37 \%$ are male.

\section{Please insert Table 1 about here}

Regarding literacy, the workers with education lower than high school (the reference category) make up most of the sample.

The sample is mostly composed of Portuguese employees. There is however a significant number of workers of other nationalities including east Europe, Africa and South America. As to the level of economic activity, the most represented ones are the manufacturing industry, the wholesale and retail business, transportation, 
communication and construction. $21 \%$ of the low wage workers in the sample live in the Lisbon area.

Table 2 presents the average and standard deviation of continuous variables included in the different regressions.

\section{Please insert Table 2 about here}

The survival model was estimated in its nonparametric version (Cox Regression) as well as the parametric version considering five different distributions $f($.$) :$ exponential, Weibull, Gompertz, log-normal and log-logistic. The exponential and Weibull distributions were estimated in the proportional hazard ratio version and the accelerated failure time version.

The statistics used in the comparison between the different models was the Akaike Information Criterion (AIC). For the parametric survival models, AIC is represented by:

$$
A I C=-2 \ln L+2(k+c)
$$

Where $k$ is the number of explaining variables in the model and $c$ is the number of specific parameters of the distribution in question. The results obtained for the parametric models estimated are found in Table 3.

\section{Please insert Table 3 about here}

The model to be chosen is the one corresponding to a lower AIC value which in our case corresponds to the log-normal model.

The log-normal regression in Table 4 is done according to the version of the model with accelerated failure time. In this case, there is an estimation of the acceleration of failure time (in other words, the time needed to escape the low wages). In case of a positive coefficient, the change from low to high wages is delayed and a negative one speeds up the shift to high wages. 


\section{Please insert Table 4 about here}

The main conclusions from this estimation are the following:

a) Women have more difficulty in leaving a low wage situation, with less likelihood of escaping low wages due to the time they remain in this situation.

b) The age of the worker lowers the likelihood of escaping a low wage situation.

c) The fact the worker completed high school or has a degree increases the likelihood of escaping a low wage situation.

d) The seniority of the worker in the company makes it difficult to escape a low wage situation.

e) As opposed to the remaining nationalities considered, the Asian immigrants present a lower likelihood of escaping a low wage situation than the Portuguese employees.

f) The workers of companies with a large workforce have an increased likelihood of escaping the low wages.

g) The age of the company is negatively related to the likelihood of its employees escaping a low wage situation.

h) The fact the company is situated in Lisbon increases the likelihood of the employee escaping the low wages.

\section{Conclusions}

This paper analyzed the time a worker took to escape a low wage situation through survival models. It estimated in depth the likelihood of getting out of a low wage situation conditioned by its duration. It also identified in different estimated models a set of characteristics of the worker, the company and the occupation which influenced the duration of a low wage situation. 
Regarding the characteristics of the worker, it follows that female workers and workers with low level education, older ones, those with more seniority in the company and those of Asian origin remain longer in a low wage situation.

As to the characteristics of the company, it has been concluded that workers in smaller and older companies located outside the Lisbon region are more likely to stay in a low wage situation. 


\section{References}

Arai, M, Asplund, R., and Barth, E. (1998) "Low pay: a matter of occupation" in R. Asplund, P. Sloane e I. Theodossiou (eds.) LowPay and Earnings Mobility in Europe, Chelthenham: Edward Elgar.

Asplund, R., Sloane, P. and Theodossiou, I. (1998) Low pay and earnings mobility in Europe, Cheltenham: Edward Elgar.

Bazen, S. (2001) "Youth and earnings mobility: the case of France in a comparative framework", LoWER European Low-Wage Employment Research Network, Working paper $\mathrm{N}^{\circ} .03$.

Blázquez, M. (2006) "The probability of leaving a low-paid job in Spain: the importance of switching into a permanent employment", Revista de Economía Laboral, 3, 58-86.

Cappellari.L. (2007) "Earnings mobility among Italian low paid workers", Journal of Population Economics, 20, 465-482.

Cappellari, L. (2002) 'Do the 'working poor' stay poor? An analysis of low pay transitions in Italy, Oxford Bulletin of Economics and Statistics, 64, 87-110.

Cappellari, L.(2000) "Low-wage mobility in the Italian labour market", International Journal of Manpower, 21, 264-290.

Cardoso A. (2006): "Wage mobility: do institutions make a difference", Labour Economics, Vol.13: 387-404.

Cardoso, A. (1998) "Earnings inequality in Portugal: high and rising?",Review of Income and Wealth, 44, 325-343.

Cardoso, A. (1997) Earnings inequality in Portugal: the relevance and the dynamics of employer behaviour, $\mathrm{PhD}$ dissertation, European University Institute.

Contini, B., Filippi, M. and C. Villosio (1998) "Earnings mobility in the Italian economy", in R. Asplund, P. Sloane and I. Theodossiou (eds.) LowPay and Earnings Mobility in Europe, Chelthenham: Edward Elgar, 15-31.

Cuesta, M. (2008) "Low wage employment and mobility in Spain", Labour: Review of Labour Economics and Industrial Relations, 22, 115-146. 
Cuesta, M. (2006) "Earnings mobility and low-wage employment in Spain: the role of job mobility and contractual arrangements", Working Paper No. 11, LoWER, European Low-Wage Employment Research Network.

Deding, C. (2002) "Low wage mobility in Denmark, Germany and the United States”, Working Paper 33, The Danish National Institute of Social Research.

Gosling, A., Machin, S. and Meghir, C. (1997) "What has happened to men's wages since the mid-1960s?”,Fiscal Studies, 15, 63-87.

Gregory, M. and Elias, P. (1994) "Earnings transitions of the low-paid in Britain, 1976-91: a longitudinal study”, International Journal of Manpower,15, 170-188.

Grün, C., Lutz, H., Mahringer, H. and Rhein, T. (2009) "Being low paid: Springboard or dead end? Evidence from administrative data in Germany and Austria", European Society of Labour Economists Annual Conference, Tallinn (Estonia).

Holzer, H., Lane, J. and Vilhiber, E. (2004) "Escaping low earnings: the role of employer characteristics and changes", Industrial and Labour Relations Review, 57, 560-578.

Keese, M., Puymoyen, A. and Swaim, P. (1998) "The incidence and dynamics of low paid employment in OECD countries" in R. Asplund, P. Sloane e I. Theodossiou, (eds.) Low Pay and Earnings Mobility in Europe, Cheltenham: Edward Elgar, 223-265.

Lucifora, C. and Salverda, W. (1998) Policies for low wage employment and social exclusion in Europe, FrancoAngeli: Milan.

Mosthaf, A., Schnabel, C. and Stephani, J. (2011) "Low-wage careers: are there dead-end firms and dead-end jobs?",Zeitschrift für ArbeitsmarktForschung - Journal for Labour Market Research, 43, 231-249.

OCDE (1999) "Earnings distribution and poverty", in Implementing OECD Jobs Strategy: assessing performance and policy, Paris: Organization for Economic Cooperation and Development, 89-1036.

OCDE (1997) Labour market policies: New challenges. Policies for low-paid workers and unskilled job seekers, Paris: Organization for Economic Cooperation and Development. 
OCDE (1996) "Earnings inquality, low-paid employment and earnings mobility", Employment Outlook, Cap. 3, Paris: Organization for Economic Cooperation and Development, 59-108.

Pavlopoulos, D., Fouarge, D., Mufells, R., and Vermunt, J. (2007) "Job mobility and wage mobility of high- and low-paid workers", Schmollers Jahrbuch, 127, 4758

Pavlopoulos, D., Mufells, R., and Vermunt, J. (2005) "Wage mobility in Europe. A comparative analysis using restricted multinomial logit regression”, OSA Working paper 2005-24, Institute of Labour Studies, Tilburg.

Sloane, P. and Theodossiou, I. (2000) "Earnings mobility of the low paid", in Gregory, M., Salverdsa, W., Bazen, S. (eds.) Labour market inequalities: problems and policies of low wage employment in international perspective, Oxford: Oxford University Press.

Sloane, P. and Theodossiou, I. (1998) "An econometric analysis of low pay and earnings mobility in Britain", in R. Asplund, P. Sloane and I. Theodossiou (eds.) Low Pay and Earnings Mobility in Europe, Chelthenham: Edward Elgar, 103-115.

Sloane, P. and Theodossiou, I. (1996) "Earnings mobility, family income and low pay”, Economic Journal, 106, 657-66.

Sloane, P. and Theodossiou, I. (1994) "The economics of low pay in Britain: a logistic regression approach”, International Journal of Manpower, 15, 130-149.

Stewart, M. and Swaffield, J. (1999) "Low pay dynamics and transition probabilities", Economica, 66, 23-42.

Van Opstal, R., Waaijers, R. and Wiggers, W. (1998) "Wage growth of low-and highskilled workers in the Netherlands", in R. Asplund, P. Sloane and I. Theodossiou (eds.) Low pay and earnings mobility in Europe, Cheltenham: Edward Elgar.

Vieira, J. (2005) "Low wage mobility in the Portuguese labour market", Portuguese Economic Journal, 4, 1-14. 
Figure 1- Number of years required to escape from low wage

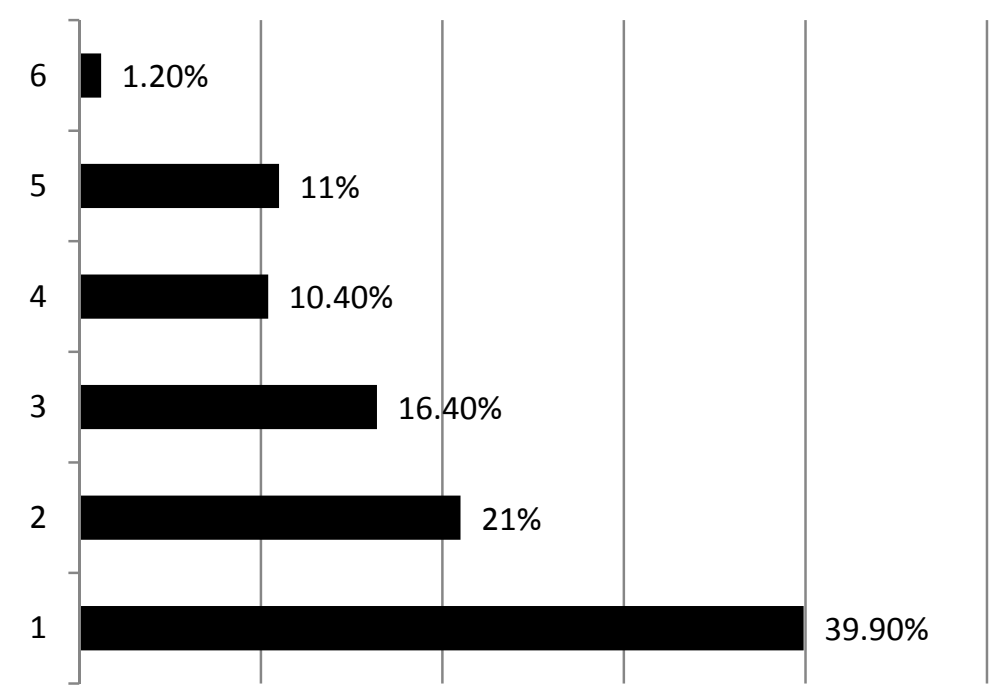


Table 1 - Categorical variables

\begin{tabular}{|c|c|c|}
\hline & Entries & $\%$ \\
\hline \multicolumn{3}{|l|}{ Personal characteristics: } \\
\hline \multicolumn{3}{|l|}{ Gender } \\
\hline Man & 707128 & 63 \\
\hline Woman & 416459 & 37 \\
\hline \multicolumn{3}{|l|}{ By level of education } \\
\hline Higher education & 17896 & 2 \\
\hline Secondary education & 115747 & 10 \\
\hline Other & 989944 & 88 \\
\hline \multicolumn{3}{|l|}{ Nationality } \\
\hline Portugal & 1060796 & 94.4 \\
\hline Africa & 16605 & 1.5 \\
\hline East Europe & 21323 & 1.9 \\
\hline Other countries in Europe & 7411 & 0.7 \\
\hline Asia & 6101 & 0.5 \\
\hline South America & 10735 & 1.0 \\
\hline Other countries & 616 & 0.1 \\
\hline \multicolumn{3}{|l|}{ Firm and job characteristics: } \\
\hline \multicolumn{3}{|l|}{ Sector of Activity } \\
\hline Agriculture, fisheries and extractive industry & 42625 & 3.8 \\
\hline Manufacturing & 349588 & 31.1 \\
\hline Construction & 108161 & 9.6 \\
\hline Wholesale/retail & 217418 & 19.4 \\
\hline Hotels and restaurants & 37896 & 3.4 \\
\hline Transports and communication & 138311 & 12.3 \\
\hline Finance & 2502 & 0.2 \\
\hline Education, Health care and other services & 227086 & 20.2 \\
\hline \multicolumn{3}{|l|}{ Region } \\
\hline Lisbon & 239509 & 21.3 \\
\hline Other & 884078 & 78.7 \\
\hline
\end{tabular}


Table 2: Continuous variables

\begin{tabular}{lrr}
\hline & Average & Standard deviation \\
\hline Age & 36.57 & 11.464 \\
Seniority & 5.2 & 6.039 \\
Number of workers in the firm & 172.61 & 934.775 \\
Firm's age & 26.11 & 6.039 \\
\hline
\end{tabular}


Table 3: AIC statistics

\begin{tabular}{lcc}
\hline & Log Likelihood & AIC \\
\hline Exponential HR & $-251080,29$ & 502204,6 \\
Exponential STA & $-251080,29$ & 502204,6 \\
Weibull HR & $-177231,02$ & 354508 \\
Weibull STA & $-177231,02$ & 354508 \\
Gompertz & $-204541,75$ & 409129,5 \\
Log-normal & $-154929,53$ & 309905,1 \\
Log-logistics & $-161823,16$ & 323692,3 \\
\hline
\end{tabular}


Table 4 - Log-normal regression

\begin{tabular}{|c|c|c|}
\hline & Coefficient & Standard error \\
\hline Constant & 1.129 & $0.005 *$ \\
\hline \multicolumn{3}{|l|}{ Personal characteristics } \\
\hline \multicolumn{3}{|l|}{ Literacy } \\
\hline Secondary education & -0.075 & $0.003 *$ \\
\hline Higher education & -0.305 & $0.008 *$ \\
\hline Age & 0.001 & $0.000 *$ \\
\hline Seniority & 0.013 & $0.000 *$ \\
\hline Woman & 0.058 & $0.002 *$ \\
\hline \multicolumn{3}{|l|}{ Nationality } \\
\hline Africa & -0.068 & $0.008 *$ \\
\hline East Europe & -0.043 & $0.007 *$ \\
\hline Other countries in Europe & -0.044 & $0.012 *$ \\
\hline Asia & 0.083 & $0.014 *$ \\
\hline South America & -0.061 & $0.010 *$ \\
\hline Other countries & -0.116 & $0.043 *$ \\
\hline \multicolumn{3}{|l|}{ Firm and job characteristics: } \\
\hline \multicolumn{3}{|l|}{ Sector of Activity } \\
\hline Manufacturing & -0.088 & $0.003 *$ \\
\hline Construction & -0.127 & $0.004 *$ \\
\hline Wholesale/retail & -0.023 & $0.003 *$ \\
\hline Hotels and restaurants & 0.161 & $0.008 *$ \\
\hline Transports and communication & 0.038 & $0.004 *$ \\
\hline Finance & -0.060 & $0.027 * *$ \\
\hline Education, Health care and other services & -0.169 & $0.004 *$ \\
\hline Number of workers & -0.000 & $0.000 *$ \\
\hline Firms age & 0.000 & 0.000 \\
\hline Lisbon & -0.016 & $0.002 *$ \\
\hline$/ \operatorname{ln\_ sig}$ & -0.7106082 & $0.001 *$ \\
\hline Sigma & 0.4913453 & 0.00081 \\
\hline Log-L & -154929.53 & \\
\hline Chi-square (21) & 17131.86 & \\
\hline $\mathrm{N}$ & 835702 & \\
\hline
\end{tabular}

